\title{
Effects of Grazing on the Vegetation of the Blackbrush Association
}

\author{
DOUGLAS L. JEFFRIES AND JEFFREY M. KLOPATEK
}

\begin{abstract}
Four communities or sites dominated by blackbrush (Coleogyne ramosissima Torr.) were studied in the Kaiparowits Basin of southern Utah and northern Arizona. One site has been heavily grazed yearlong for about 100 years; the second has been lightly to moderately grazed in winter for 3 years; the third has had 10 years of recovery from heavy grazing; and the fourth is a relic, ungrazed blackbrush ecosystem. Soils were 87 to $99 \%$ sand and gravel with mean pH's 8.2 to 8.5. The relic site had significantly more herbaceous vegetation cover (composed primarily of perennial grasses) and total cover than all other sites. The relic site also had significantly more shrub and cryptogamic cover than the heavily grazed and recovery sites. The recovering site showed no significant differences than the heavily grazed site for any of the measured parameters.
\end{abstract}

Key Words: Coleogyne ramosissima Torr., cryptogamic crust, relic community, Kaiparowits Basin.

Blackbrush (Coleogyne ramosissima Torr.), the dominant species of the blackbrush association, occurs in the southern part of the Great Basin Desert shrub biome from southwestern Colorado, southeastern Utah, and northern Arizona to the northern Mohave Desert region of southern Nevada and California (Turner 1982). Provenza and Urness (1981) comment that the species blackbrush occurs in nearly monospecific stands throughout its range in the southwestern United States. The blackbrush community is particularly well developed in the southeastern Great Basin Desert (Turner 1982) along the Colorado River drainage system (Cronquist et al. 1972). The blackbrush association encompasses several million hectares in the Southwest and yet is probably the least studied major vegetation type in the U.S. (Bowns and West 1976, Turner 1982).

The most important economic use of blackbrush-dominated areas is for winter grazing by domestic livestock, especially sheep, and by large ungulate wildlife, primarily mule deer and desert bighorn sheep (USDA Forest Service 1937, Humphrey 1953, Leach 1956, Sampson and Jespersen 1963, Bradley 1965, Bowns and West 1976).

The shrubs of the blackbrush association are widely spaced with large areas of bare interspace (Rickard and Beatley 1965) and act as "islands of fertility" for nutrients and moisture (Bowns 1973). Herbaceous plants, mainly annual and perennial grasses, occur in the interspace, but their overall cover may be low (Humphrey 1953, 1955, Rickard and Beatley 1965, Bowns 1973). A community of nonvascular cryptogamic plants may also be found in the interspace, sometimes forming a recognizable crust. This cryptogamic crust has been reported to be important in reducing erosion (Booth 1941, Fletcher and Martin 1948, Loope and Gifford 1972), and the portions of the crust with blue-green algae or lichens with a bluegreen algal phycobiont may be important sources of nitrogen for desert ecosystems (Snyder and Wullstein 1973, Rychert and Skujins 1974, West and Skujins 1977).

The objective of this study was to investigate the vegetative features on blackbrush-dominated sites with low or high grazing pressures, a site where grazing pressure has been removed, and a

\footnotetext{
Authors are graduate associate and associate professor, Department of Botany and Microbiology, Arizona State University, Tempe 85287.

The authors thank the National Park Service, Glen Canyon National Recreation Area, for supplies and site transportation. We also thank Carole Coe Klopatek for assistance in data collection.

Manuscript accepted 24 April 1987
}

relic ungrazed community to assess what changes, if any, had been brought about by grazing.

\section{Site Descriptions}

Four sites were studied in the Kaiparowits Basin of southern Utah and northern Arizona. Three sites are within the Glen Canyon National Recreation Area, and one is on the Navajo Indian Reservation. The Navajo Indian Reservation site (NR) ( $1,420 \mathrm{~m}$ elev.) is $11 \mathrm{~km}$ east of the Glen Canyon Dam and $14 \mathrm{~km}$ south of Romana Mesa. This site has experienced yearlong, prolonged, heavy grazing by cattle, horses, sheep, and goats since the 1880's. The Ahlstrom Point site (AP) (1,415 m elev.) is $17 \mathrm{~km}$ northeast of the Glen Canyon Dam and $2.5 \mathrm{~km}$ northwest of Romana Mesa. This site had experienced little or no domestic ungulate grazing due to its lack of available water until 1981 when a stock tank was constructed $2 \mathrm{~km}$ to the north. Since 1981 it has had light to moderate winter grazing by cattle. Gunsight Bench (GB) $(1,200 \mathrm{~m}$ elev.) is $9 \mathrm{~km}$ northeast of the Glen Canyon Dam and $1 \mathrm{~km}$ south and directly below Romana Mesa. It was heavily grazed by cattle until 1974 when it was isolated from grazing by the formation of Lake Powell. Romana Mesa (RM) (1,450 m elev.) is a completely isolated relic area atop a mesa $16 \mathrm{~km}$ northeast of the Glen Canyon Dam. It is a pristine ecosystem that has probably never been grazed or browsed by any ungulate.

Precipitation has been measured at Page, Ariz., (elev. 1,320 m), located $4 \mathrm{~km}$ southwest of the Glen Canyon Dam, since 1957, and at the Wahweap Ranger Station (elev. 1,170 m), located $7 \mathrm{~km}$ north of the Glen Canyon Dam, since 1963. Calculations from the Climatological Data reports (NOAA 1957-1985) of the mean annual precipitation through 1985 were $162 \mathrm{~mm}$ for Page and $165 \mathrm{~mm}$ for Wahweap. The period from 1978 to 1983 showed a marked increase in annual precipitation, with a mean of $248 \mathrm{~mm}$ for both stations combined. The mean for the years 1957 to 1977 was only $133 \mathrm{~mm}$.

\section{Methods}

Five, $100-\mathrm{m}$ line transects, radiating from a central point in random directions, were generated within each site. Twenty soil samples, consisting of 3 composites each, were collected from each site for analysis. Two depths $(0-5$ and $10-15 \mathrm{~cm})$ were sampled from under the shrub canopy and in the interspace on each transect. Particles $>2 \mathrm{~mm}$ were removed by sieving and weighed. Soil texture was analyzed by the Bouyoucos hydrometer method (Bouyoucos 1928). Soil pH was determined using a 1:1 slurry and glass-rod pH meter and converted to hydrogen ion concentrations for statistical analysis.

The shrub species were measured every $10 \mathrm{~m}$ along the transects by the point-quarter method (Cottam et al. 1953). Measurements included height, crown diameter (widest point), width (perpendicular at widest point), and distance to the shrub center. The total density per hectare was determined by dividing $10,000\left(\mathrm{~m}^{2} \mathrm{ha}^{-1}\right)$ by the squared average distance $(m)$ between shrubs. Canopy cover was then calculated by multiplying the total density per hectare by the mean canopy area of measured shrubs. Ten $0.5-\mathrm{m}^{2}$ rectangular plots located randomly along each transect were used to estimate the cover of herbaceous species. Four $0.005-\mathrm{m}^{2}$ plots were placed at the corners of the $0.5-\mathrm{m}^{2}$ plots to sample the cryptogamic vegetation. No tree species occurred on any of the 4 sites. 
The 4 sites were surveyed during the summer of 1984 and the data reflect mainly perennial plant cover. Observance of spring annuals in 1985 indicated that the occurrence of annual herbaceous vegetation was very sparse. Nomenclature follows Lehr (1978).

Statistical analysis was performed using the ANOVA procedure and the Tukey studentized range test of the Statistical Analysis System (SAS 1985).

\section{Results}

Mean particle size distribution of the soils ranged from 89.6 to $92.8 \%$ sand, 2.5 to $4.8 \%$ silt, 1.4 to $2.2 \%$ clay, and 1.9 to $5.0 \%$ gravel. Only 2 samples $(n=80)$ had less then $90 \%$ combined percent sand and gravel. There were some significant statistical differences in sand/silt/clay fractions between sites $(P<0.05)$, but the actual differences were so small that it is unknown whether they would be ecologically significant. There was no significant difference in soil texture within a site. The mean $\mathrm{pH}$ was 8.2 to 8.5 and ranged from 8.1 to 8.9. The $\mathrm{pH}$ was not significantly different within sites $(P<0.05)$, but the relict site $(\mathrm{RM})$ had a significantly lower $\mathrm{pH}$ than the other sites. Again, it is not known if this difference is large enough to be ecologically significant.

The relic (RM) and lightly grazed (AP) sites had significantly more shrub cover than the other sites (Table 1). The dominant shrub on all sites was blackbrush, comprising 82.5 to $94.5 \%$ of the shrub cover.

The relict site (RM) had significantly more herbaceous vegetation than all the other sites (Table 1), which were not significantly different from one another. The reduced cover of Indian ricegrass
Table 1. Shrub, herbaceous, and cryptogamic vegetation cover for blackbrush communities studied in a Kaiparowits Basin.

\begin{tabular}{|c|c|c|c|c|}
\hline \multirow[b]{2}{*}{ Parameter } & \multicolumn{4}{|c|}{ Community History (Site) } \\
\hline & $\begin{array}{l}\text { Relict } \\
\text { (RM) }\end{array}$ & $\begin{array}{l}\text { Light } \\
\text { grazing } \\
\text { (AP) }\end{array}$ & $\begin{array}{l}\text { Heavy } \\
\text { grazing } \\
(\mathrm{NR})\end{array}$ & $\begin{array}{l}\text { Recover- } \\
\text { ing } \\
\text { (GB) }\end{array}$ \\
\hline $\begin{array}{l}\text { Total shrub cover }\left(\mathrm{m}^{2} \mathrm{ha}^{-1}\right) \\
\text { Blackbrush cover, } \% \text { of total } \\
\text { shrub cover } \\
\text { Mcan arca } / \text { shrub }\left(\mathrm{m}^{2}\right) \\
\text { Mean distance }(\mathrm{m}):\end{array}$ & $\begin{array}{l}3645 a^{*} \\
87 a \\
0.31 b c \\
0.94 b\end{array}$ & $\begin{array}{l}83 a \\
0.28 c \\
0.98 b\end{array}$ & $\begin{array}{l}92 \mathrm{a} \\
0.16 \mathrm{~d} \\
1.08 \mathrm{~b}\end{array}$ & $\begin{array}{l}95 \mathrm{a} \\
0.36 \mathrm{~b} \\
1.56 \mathrm{a}\end{array}$ \\
\hline $\begin{array}{l}\text { Total herbaceous cover } \\
\left(\mathrm{m}^{2} \text { ha }{ }^{-1}\right) \\
\text { Orhy' }{ }^{1} \text { cover, \% total } \\
\text { herbaceous cover } \\
\text { Hija }{ }^{2} \text { cover, \% total } \\
\text { herbaceous cover }\end{array}$ & $1047 a$ & $256 \mathrm{~b}$ & $102 b$ & $127 \mathrm{~b}$ \\
\hline $\begin{array}{l}\text { Total cryptogamic cover } \\
\left(\mathrm{m}^{2} \mathrm{ha}^{-1}\right)\end{array}$ & $2129 a$ & $1196 a$ & $70 \mathrm{~b}$ & $50 \mathrm{~b}$ \\
\hline Total cover $\left(\mathrm{m}^{2} \mathrm{ha}^{-1}\right)$ & $6821 \mathrm{a}$ & $4326 \mathrm{~b}$ & $1576 c$ & $1549 c$ \\
\hline
\end{tabular}

IOryzopsis hymenoides (R. \& S.) Ricker, Indian ricegrass.

${ }^{2}$ Hilaria jamesii (Torr.) Benth., galleta grass.

* Means in the same row followed by the same letter are not significantly different at the 0.05 probability level as determined by Tukey's studentized range test.

Table 2. Presence (X) of species on sites studied in the blackbrush association in Kaiparowits Basin.

AGAVACEAE

Yucca angustissima Engelm.

Opuntia erinacea Engelm. \& Bigcl.

CACTACEAE

Atriplex canescens (Pursh) Nutt.

A. confertifolia (Torr. \& Frem.) Wats.

Grayia spinosa (Hook.) Moq.

Artemisia filifolia Torr.

Chrysothamnus nauseosus (Pall.) Britt.

Xanthocephalum wrightii Gray

Lepidium montanum Nutt.

CRUCIFERAE

Ephedra torreyana Wats.

E. viridis Cov.

Bromus rubens $\mathbf{L}$.

Erioneuron pulchellum (H.B.K.) Tateoka

Hilaria jamesii (Torr.) Benth.

Oryzopsis hymenoides (R. \& S.) Ricker

Sporobolus cryptandrus (Torr.) Gray

Stipa sp.

Vulpia octoflora (Walt.) Rydb.

Astragalus sp.

LEGUMINOSAE

GRAMINEAE

Lupinus sp.

MALVACEAE

Sphaeralcea grossulariaefolia (H. \& A.) Rydb.

Plantago sp.

PLANTAGINACEAE

POLYGONACEAE

Eriogonum inflatum Torr. \& Frem.

Eriogonum sp.

Coleogyne ramosissima Torr

CHENOPODIACEAE

COMPOSITAE

\begin{tabular}{lccc}
\multicolumn{5}{c}{ Community } & History (Site) \\
\hline Relict & Light grazing & Heavy grazing & Recovering \\
(RM) & (AP) & (NR) & (GB)
\end{tabular}

$\mathbf{X}$

$\mathbf{X}$

$\mathbf{x}$

$\mathbf{X}$

\begin{tabular}{|c|c|c|}
\hline $\mathbf{X}$ & $x$ & $\begin{array}{l}\mathbf{X} \\
\mathbf{X} \\
\mathbf{X}\end{array}$ \\
\hline $\mathbf{X}$ & $\mathbf{X}$ & \\
\hline $\begin{array}{l}\mathbf{X} \\
\mathbf{X}\end{array}$ & $\begin{array}{l}\mathbf{X} \\
\mathbf{X}\end{array}$ & $\mathbf{X}$ \\
\hline$X$ & $\mathbf{X}$ & $\begin{array}{l}\mathbf{X} \\
\mathbf{X}\end{array}$ \\
\hline $\mathbf{X}$ & $X$ & $\mathbf{X}$ \\
\hline $\mathbf{X}$ & $X$ & $\begin{array}{l}\mathbf{X} \\
\mathbf{X}\end{array}$ \\
\hline $\mathbf{X}$ & $\mathbf{X}$ & $\begin{array}{l}\mathbf{X} \\
\mathbf{X}\end{array}$ \\
\hline
\end{tabular}

$\mathbf{X}$

$\mathbf{X}$

$\mathbf{X}$

$\mathbf{X}$

$\mathbf{X}$

X

$\mathbf{X}$

X

$\mathrm{X}$

$\mathrm{X}$

$\mathrm{X}$

$\mathrm{X}$

$\mathbf{X}$

X

$\mathrm{X}$ 
(Oryzopsis hymenoides (R. \& S.) Ricker), a very palatable grass, was the primary reason for this difference. The cover of galleta grass (Hilaria jamesii (Torr.) Benth.), a grass tolerant to grazing, was not significantly different between sites, but as the total herbaceous vegetation cover decreased, the relative percent cover of this species increased.

The relict (RM) and lightly grazed (AP) sites had significantly more cryptogamic cover then the other sites (Table 1), although the AP had only half as much as $R M$ and was significant at the $p<.10$ lcvel. The decrease in cryptogams was mainly due to a loss of crust in the interspace, with the remaining cryptogams being mosses and lichens located under the blackbrush canopy.

The relict site (RM) had significantly more total cover than all other sites, and the lightly grazed site (AP) had significantly more than the heavily grazed (NR) and recovery (GB) sites (Table 1).

\section{Discussion}

The data indicate that even light grazing may reduce the cryptogamic cover in this system, and heavier grazing almost completely eliminates it. This agrees with the findings of Kleiner and Harper (1977), West and Skujins (1977), Johansen et al. (1981), Anderson et al. (1982), and Rychert et al. (1982). Highly disturbed areas that were subsequently protected from grazing were reported to be recovered by a cryptogamic crust in 14 to 18 years (Anderson et al. 1982), but Callison et al. (1985) found that the cryptogamic crust in a blackbrush community that was removed by fire had no recovery in 19 years. The recovering site (GB) has had virtually no recovery of cryptogams in 10 years despite 6 years of much greater than normal precipitation.

Herbaceous vegetation cover was greatly reduced on the grazed sites as compared to the relic site. There was also a change in the dominant grass, with Indian ricegrass being dominant on the relic site, and galleta grass on the others. Because the relic site is not accessible to wild ungulates, it is hard to assess how much of the difference between sites can be attributed to wild versus domestic animal grazing. The absence of Indian ricegrass on the recovering site (GB) is probably due to the very slow recovery of arid systems (Westoby 1980), the probable continued grazing by the rabbit population, or a combination of both factors.

The shrub cover was less on the heavily grazed (NR) and recovering (GB) sites compared to the relic (RM) and lightly grazed (AP) sites. Again, it is hard to assess the difference that may be attributed to wild or domestic ungulates.

If we assume that the wild ungulates contribute little to the differences seen in the data, we can make the following conclusions. Cryptogamic cover is reduced by grazing, with severe damage being done by heavy grazing usage. It is possible that the development of cryptogamic crusts on sandy or gravelly soils that are characteristic of the blackbrush ecosystem is different from that on heavier textured soils, and recovery is a much more prolonged process. Cover of herbaceous vegetation is reduced by grazing, primarily due to the removal of the perennial grasses that are not grazing tolerant. Grasses that are grazing tolerant are able to maintain their presence in the system, but do not necessarily benefit from the reduction in cover of the other species. The shrub cover is reduced by heavy grazing. Blackbrush is able to tolerate heavy grazing and survive, but at much reduced cover. Recovery of all parameters is very slow in this system, perhaps due to edaphic factors related to the sandy soil, the lack of precipitation, and compounded by grazing of large and small wild animals.

The occurrence of blackbrush on Romana Mesa, an isolated area probably untouched by man or domestic livestock in its entire geologic history, supports one of the theories of West (1969) that it is a climax species. The data from Romana Mesa also support the observations that blackbrush naturally occurs in nearly monotypic stands (Provenza and Urness 1981).

\section{Literature Cited}

Anderson, D.C., K.T. Harper, and R.C. Holmgren. 1982. Recovery of cryptogamic soil crusts from grazing on Utah winter ranges. J. Range Manage. 35:355-359.

Booth, W.L.E. 1941. Algae as pioneers in plant succession and their importance in erosion control. Ecology. 22:38-46.

Bowns, J.E. 1973. An autecological study of blackbrush (Coleogyne ramosissima Torr.) in southwestern Utah. Ph.D. Thesis. Utah State Univ., Logan. Diss. Abstr. 74:13,202.

Bowns, J.E., and N.E. West. 1976. Blackbrush on southwestern Utah rangelands. Utah Agr. Exp. Sta. Rep. 27. Utah State Univ., Logan.

Bouyoucos, G.J. 1928. The hydrometer method for making a very detailed mechanical analysis of soils. Soil Sci. 26:233-238.

Bradley, W.G. 1965. A study of the blackbrush plant community on the Desert Game Range. Trans. Desert Bighorn Council. 9:56-61.

Callison, J., J.D. Brotherson, and J.E. Bowns. 1985. The effects of fire on the blackbrush (Coleogyne ramosissima) community of southwest Utah. J. Range Manage. 38:535-538.

Cottam, G., J.T. Curtis, and B.W. Hale. 1953. Some sampling characteristics of a population of randomly dispersed individuals. Ecology. 34:741-757.

Cronquist, A., A.H. Holmgren, N.H. Holmgren, and J.L. Reveal. 1972. Intermountain flora. Vascular plants of the intermountain west U.S.A. Vol. I. Hafner Publ. Co. Inc., New York.

Fletcher, J.E., and W.P. Martin. 1948. Some effects of algae and molds in the rain-crust of desert soils. Ecol. 29:95-100.

Humphrey, R.R. 1953. Forage production on Arizona ranges, III. Mohave County. A study in range condition. Arizona Agr. Exp. Sta. Bull. 244.

Humphrey, R.R. 1955. Forage production on Arizona ranges, IV. Coconino, Navajo, Apache Counties. A study in range condition. Arizona Agr. Exp. Sta. Bull. 266.

Johansen, J.R., S.R. Rushforth, and J.D. Brotherson. 1981. Subaerial algae of Navajo National Monument, Arizona. Great Basin Natur. 41:433-439.

Kleiner, E.F., and K.T. Harper. 1977. Soil properties in relation to cryptogamic ground cover in Canyonlands National Park. J. Range Manage. 30:202-205.

Leach, H.R. 1956. Food habits of the Great Basin Deer herds of California. California Fish \& Game. 38:211-224.

Lehr, J.H. 1978. A catalogue of the flora of Arizona. Desert Botanical Garden, Phoenix, Ariz.

Loope, W.L., and G.F. Gifford. 1972. Influence of a soil microbial crust on selected properties of soil under pinyon-juniper in southeastern Utah. U. Soil Water Conserv. 27:164-167.

National Oceanic and Atmospheric Administration. 1957-1985. Climatological Data. Arizona. Vols. 61-89. National Oceanic and Atmospheric Administration, Asheville, North Carolina.

Provenza, F.D., and P.J. Urness. 1981. Diameter-length, weight relations for blackbrush branches. J. Range Manage. 30:68-70.

Rickard, W.H., and J.C. Beatley. 1965. Canopy-coverage of the desert shrub vegetation mosaic of the Nevada Test Site. Ecology. 46:524-529.

Rychert, R.C., and J. Skujins. 1974. Nitrogen fixation by bluegreen algaelichen crusts in the Great Basin Desert. Soil Sci. Soc. Amer. Proc. 38:768-771.

Rychert, R.C., J. Skujins, D. Sorensen, and D. Procella. 1982. Nitrogen fixation by lichens and free-living microorganisms in deserts. p. 20-30. In: West, N.E. and J. Skujins, eds. Nitrogen in desert ecosystems. Dowden, Hutchinson and Ross, Inc., New York.

Sampson, A.W., and B.J. Jespersen. 1963. California range brushlands and browse plants. California Agr. Exp. Sta. Manual 33.

SAS Institute Inc. 1985. SAS user's guide: Statistics, Version 5 Edition. SAS Institute Inc., Cary, N.C.

Snyder, J.M., and L.H. Wullstein. 1973. The role of desert cryptogams in nitrogen fixation. Amer. Midl. Natur. 90:257-265.

Turner, R.M. 1982. Cold-temperate desertlands. Great Basin desertscrub. p. 144-155. In: Brown, D.E., ed. Desert plants. vol. 4. Univ. of Arizona, Tucson.

USDA Forest Service. 1937. Range plant handbook. U.S. Government Printing Office, Washington, D.C.

West, N.E. 1969. Soil-vegetation relationships in arid southeastern Utah. In: International conference on arid lands in a changing world. Univ. of Arizona.

West, N.E. and J. Skujins. 1977. The nitrogen cycle in North American cold-winter semi-desert ecosystems. Oecol. Plant. 12:45-53.

Westoby, M. 1980 . Elements of a theory of vegetation dynamics in arid rangelands. Israel J. Bot. 28:169-194. 